\title{
A CLINICAL STUDY ON THE USE OF T.H.A.M. FOR BUFFERING A.C.D. BLOOD PRIOR TO USE IN EXTRACORPOREAL BYPASS PROCEDURES*
}

\author{
C. D. Elton, M.D., E. A. Gain, M.D., And G. Moonie, M.D.
}

THE NUMBER OF CASES coming to surgery during the last year which required the use of the cardiopulmonary bypass has put a severe strain on the Red Cross for the provision of donors of fresh heparinized blood. In an effort to minimize this, A.C.D. blood reconstituted with calcium and hejparin in the manner described by Foote, Trede, and Maloney ${ }^{1}$ has been frequently used during the past year at the University Hospital in Edmonton for priming the pump loxygenator for these "open heart" procedures. At this centre it has been found that the use of this blood is not without severe drawbacks. Foote and co-workers concentrated in their studies mainly on finding the correct amount of calcium chloride and heparin to add to the A.C.D. blood in order to combine a satisfactory myocardial function with an adequate anticoagulant effect. It was found, by perfusing the coronary arteries of dogs, that on an average 11.6 moles of calcium per litre of A.C.D. blood gave optimum calcium levels for maximum ventricular function. They did not appear to have had much trouble from the $\mathrm{pH}$ of this mixture and report a $\mathrm{pH}$ of 7.06 , although in their animal experiments on full cardiopulmonary bypass the $\mathrm{pH}$ dropped from 7.40 to 7.13 -a dangerously low figure. In their clinical work they reported a $\mathrm{pH}$ of 7.3 during perfusion using heparinized blood, and about 7.25 with the reconstituted A.C.D. blood after an initial $\mathrm{pH}$ of 6.96 in the first few minutes. There was little difference between the two groups thereafter. In the discussion they point out that the large amount of citrate is initially buffered by the extracellular compartment of the body fluid before being oxidized to bicarbonate by the muscles, liver, and kidneys.

In most cases it has been found that this A.C.D. blood mixture has "worked satisfactorily, but the $\mathrm{pH}$ of this blood is usually between 6.7 and 6.8. It seems undesirable.and even dangerous to suddenly perfuse a patient with a large volume of very acid blood. This is especially true in the case of the deteriorating patient, where it is necessary to go on full bypass suddenly without the benefit of a slow run-in on partial bypass first. We have found that the patients who are in good physical shape seem to be able to take this insult to their system. The sick ones who, because of their poor cardiac output, may have a mild degree of metabolic acidosis, and, as Foote suggested, the children, never seem to be able to recover from the profound degree of metabolic acidosis produced (see Figs. 1 and 2).

This initial degree of severe acidosis may be of critical importance later, as Boue, Hermann, and Shaw ${ }^{2}$ have shown that in dogs a short-lived but severe acidosis may produce permanent impairment of myocardial function. They also showed that at a $\mathrm{pH}$ of 7.1 ventricular contraction diminished to 50 per cent of

-From the Department of Anaesthesia, University of Alberta Hospital, Edmonton, Alberta. 


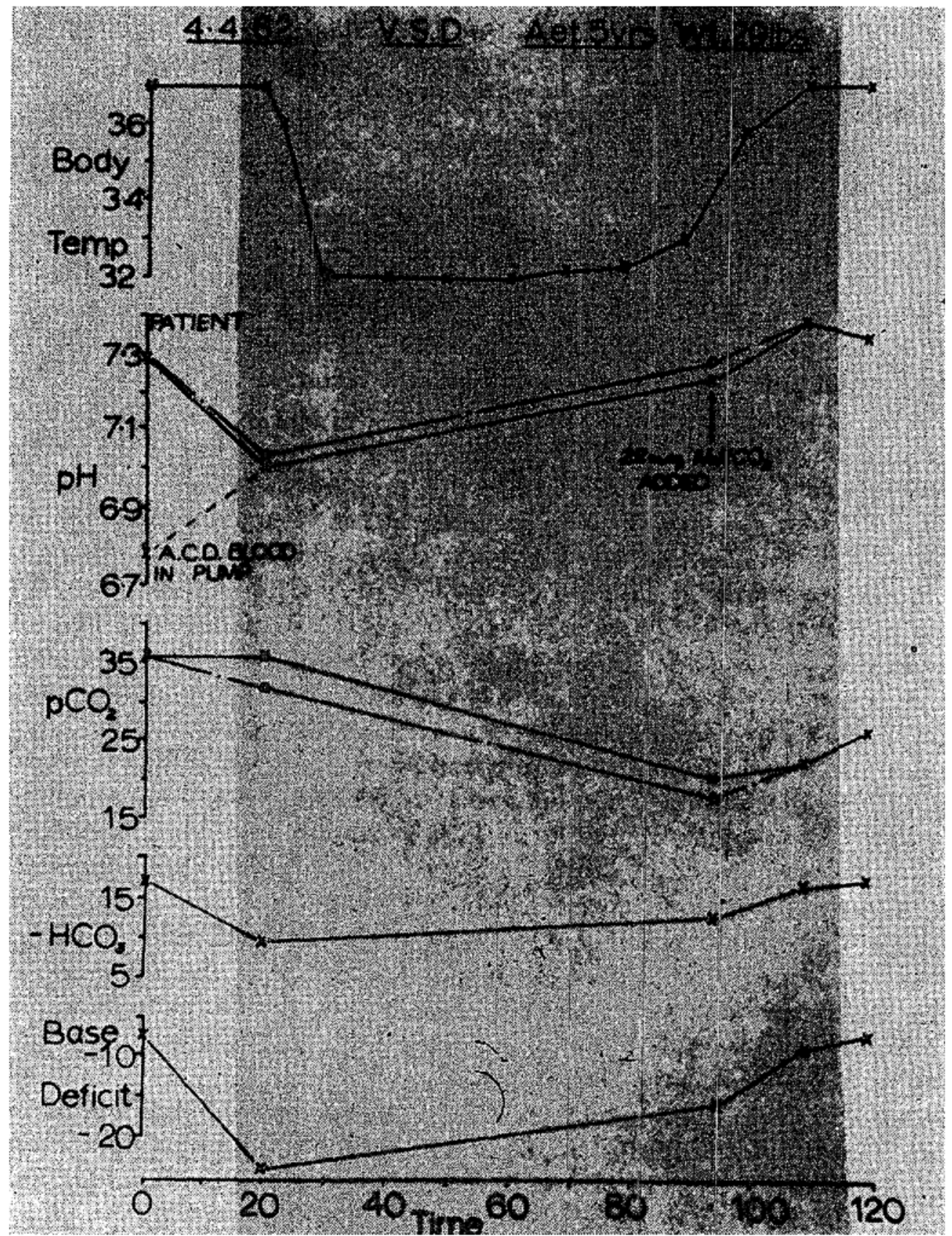

Figure 1, A.S.D. repair on a $29-1$ b. child 5 years of age. A.C.D. blood. The severe drop in $\mathrm{pH}$ is well shown as the result of a marked loss of bicarbonate. No $\mathrm{CO}_{2}$ was used in the oxygenator in this cease.

In the figures the time marked is the time elapsed from the drawing of the first blood samples, the shaded area covers the period on bypass, readings marked with a circle are temperature-corrected readings, and actual measurements obtained are marked with an $X$.

the control values and the heart seemed dilated. Below a $\mathrm{pH}$ of 7.0 effective left ventricular activity ceased and in most cases cardiac arrest occurred. He also showed that whilst T.H.A.M.-a recently introduced buffer-would buffer the blood satisfactorily, both calcium and T.H.A.M. were required for adequate myocardial function. 


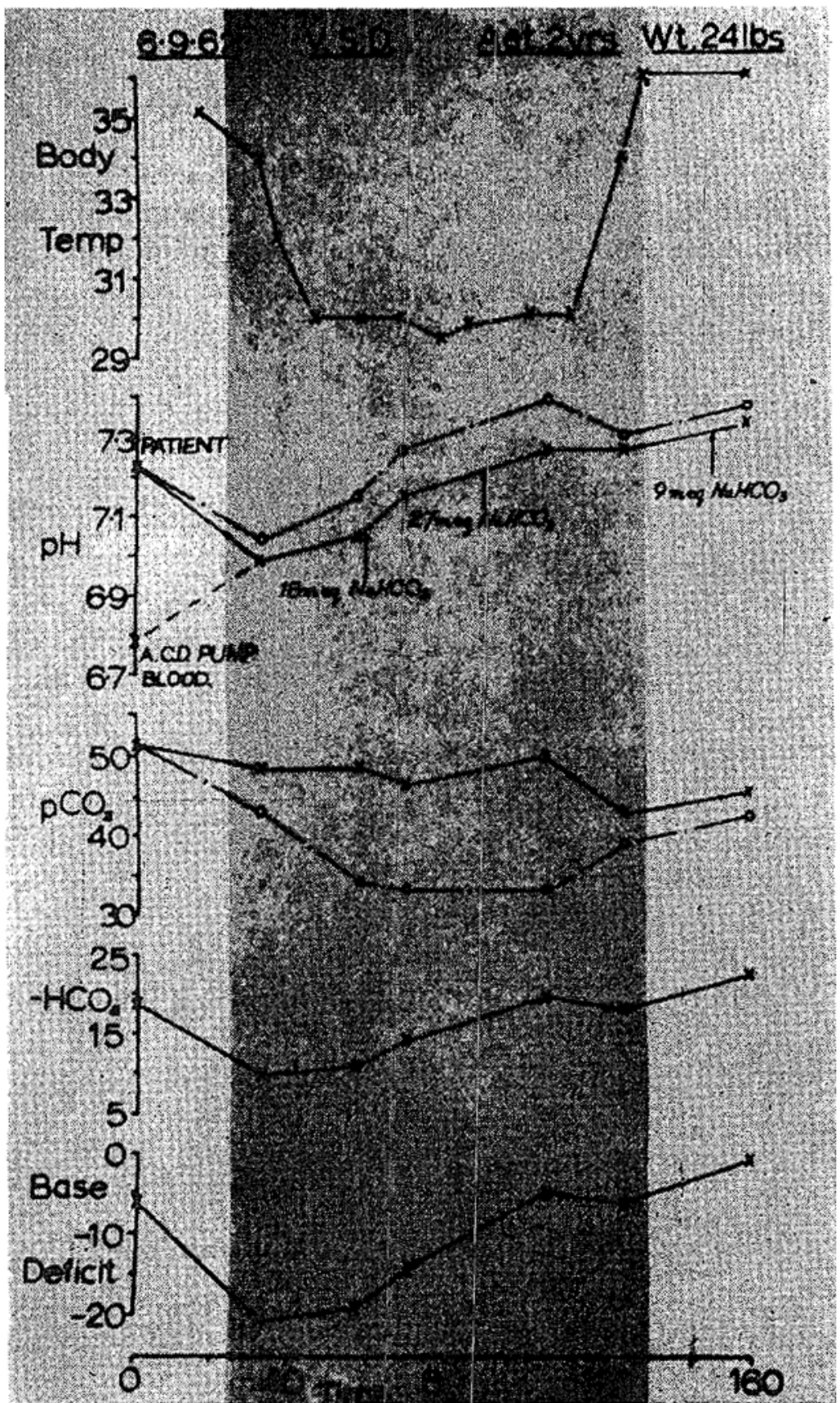

Frgune 2. V.S.D, repair on a 24-lb. child 2 years of age. A.C.D. blood. The severe drops in $\mathrm{pH}$ and bicarbonate values are well shown.

This effect on the myocardium of a low $\mathrm{pH}$, albeit temporary! may be of critical importance in some of our patients because, when not corrected, some of their $\mathrm{pH}$ readings were close to 7.1 or even lower. It was suspected that this initial bout of severe acidosis might account for the oceasional patient who could not be taken off bypass because of poor myocardial function.

Ebert and co-workers ${ }^{3}$ varied the $\mathrm{pH}$ artificially by means of sodium bicarbonate and hydrochloric acid on dogs undergoing procedures on cardiopulmonary bypass and profound hypothermia. They found that dogs that were alkalotic 
prior to bypass had a much better ventricular function following a period of 30 minutes of anoxia than the controls (normal $\mathrm{pH}$ ) and those deliberately given an acidosis. Ebert concluded that at a high flow rate the induction of acidosis during profound hypothermia serves no useful purpose and his evidence.suggests that a high $\mathrm{pH}$ may be desirable if a period of anoxia is necessary. He also states: "The cellular damage which occurs in the anoxic heart has been shown to be related to the low $\mathrm{pH}$ which results from anoxia. Increased intracellular acidity leads to activation of proteolytic enzymes in the myocardium with subsequent destruction of apoenzyme protein and alteration of various metabolic systems. If the observed depression of ventricular function after aortic occlusion results from such a mechanism the benefit of a high $\mathrm{pH}$ at the time of aortic occlusion can be explained by its effect on delaying the activation of these proteolytic enzymes." It has also been suggested by Schweizer and Howland ${ }^{4}$ that the hyperkaliaemia in massive transfusions is not a product of the A.C.D. blood per se but a result of low $\mathrm{pH}$ with massive tissue trauma a contributory factor.

It seemed very desirable to us therefore to perfuse the patient with blood having a normal $\mathrm{pH}$. As fresh heparinized blood is at a premium we decided to buffer reconstituted A.C.D. blood with T.H.A.M. as described by Boue et al. ${ }^{2}$ Sodium bicarbonate is not suitable for this purpose as it means loading a cardiac patient with sodium. It also tends to convert a metabolic acidosis to a respiratory one, which might be almost as embarrassing in the immediate post-bypass period. T.H.A.M. was therefore titrated into the oxygenator to buffer the priming blood back to a near normal $\mathrm{pH}$.

T.H.A.M. is an organic buffer having the formula:<smiles>NC(CO)(CO)CO</smiles>

The initials T.H.A:M. stand for its name tris(hydroxymethyl)amino methane. It is classified as a weak base and in the presence of an acid the following reaction takes place:

$$
\begin{gathered}
\mathrm{HA}+\mathrm{NH}_{2} \mathrm{C}\left(\mathrm{CH}_{2} \mathrm{OH}\right)_{3} \rightarrow \mathrm{A}^{-}+\mathrm{NH}_{3}+\mathrm{C}\left(\mathrm{CH}_{2} \mathrm{OH}\right)_{3} \\
\mathrm{~A}^{-} \text {in a biological system may be } \mathrm{HCO}_{3}^{-}, \mathrm{Cl} \text {, or lactate }
\end{gathered}
$$

The reaction proceeds from left to right as the acid concentration increases. It has been used successfully by a large number of investigators since its introduction by Nahas, Jordon, and Ligou ${ }^{5}$ in 1959 for both respiratery and metabolic acidosis. It has the additional advantage over sodium buffers that it penetrates the cellular membrane more easily and hence is more effective. It is highly soluble in water but neither it nor its solution will absorb $\mathrm{CO}_{2}$ from the air. In a 3.6 per cent ( 0.3 molar) solution it is isomolar with blood. It also has a diuretic effect but to the anaesthetist the possible production of a severe degree of hypoglycaemia is of more importance. However, this effect is only likely to arise when sufficient has been given to raise the $\mathrm{pH}$ above the normal tange.

\section{METHOD}

Dr. Buchanan, the director of the Blood Transfusion Research Unit at the University of Alberta Hospital, co-operated in this work and.checked to make 
sure that this agent would not have any haemolyzing effect on the blood in the reservoir and oxygenator of the pump.

Samples'were set up using the same relative amounts of T.H.A.M. as we would use in the pump and were checked for haemolysis. The isomolar solution (3.6\%) was used and the samples of blood incubated for 24 hours at tenneratures of $4^{\circ}$ C., $20^{\circ}$ C. (R.T.), and $37^{\circ}$ C. No trace of haemolysis was observed.

The filters of the pump were checked originally but no signs of precipitation

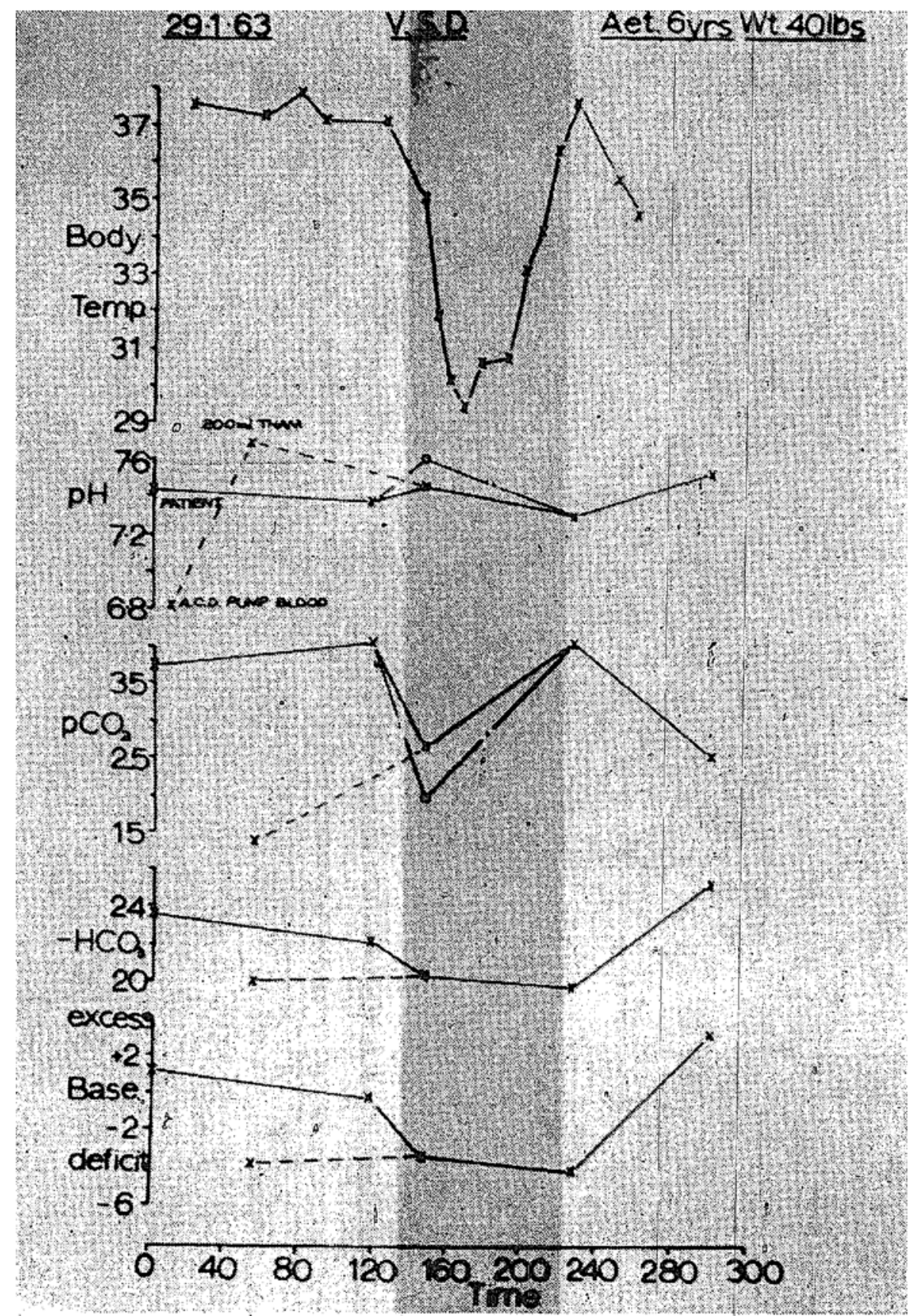

Figure 3..V.S.D. repair on a 40-lb. child 6 years of age. A.C.D. blood buffered with T.H.A.M. The $\mathrm{pH}$ actually rose in this case because of a drop in $p \mathrm{CO}$., but the bicarbonate remained almost normal. 
were found. The oxygenator was perfused with a mixture of approximately.97.5 per cent oxygen and $2 \frac{13}{2}$ per cent $\mathrm{CO}_{2}$.

Our results were obtained by means of an AME 1 Astrup micro-equipment $\mathrm{pH}$ meter, using a Sigaard Anderson and Engel nomogram for the $p \mathrm{CO}_{2}$ and bicarbonate readings. Adjustments for temperature were made using the Rosenthal factor ${ }^{6}$ for $\mathrm{pH}$ and using the Severinghaus nomogram for $p \mathrm{CO}_{2}$. A standardized technique was used throughout.

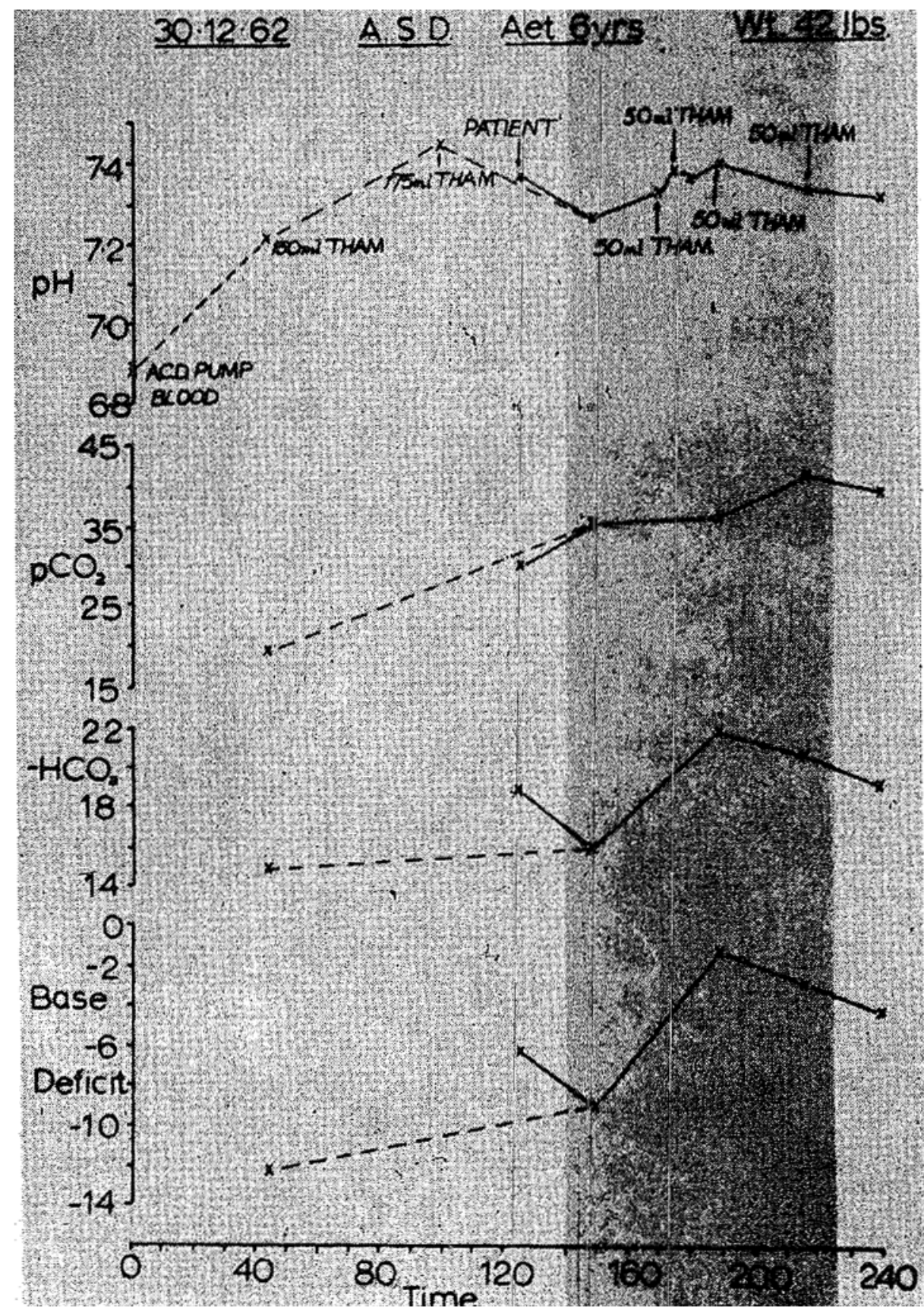

Figune 4. A.S.D. repair on a 42-lb. child 6 years of age. A.C.B. blood buffered with T.H.A.M. Little change is noted in values shown on start of bypass. Difficulty with the perfusion accounted for the use of T.H.A.M. during bypass to counteract the resulting tendency to acidosis as shown in the $\mathrm{pH}$ readings. 


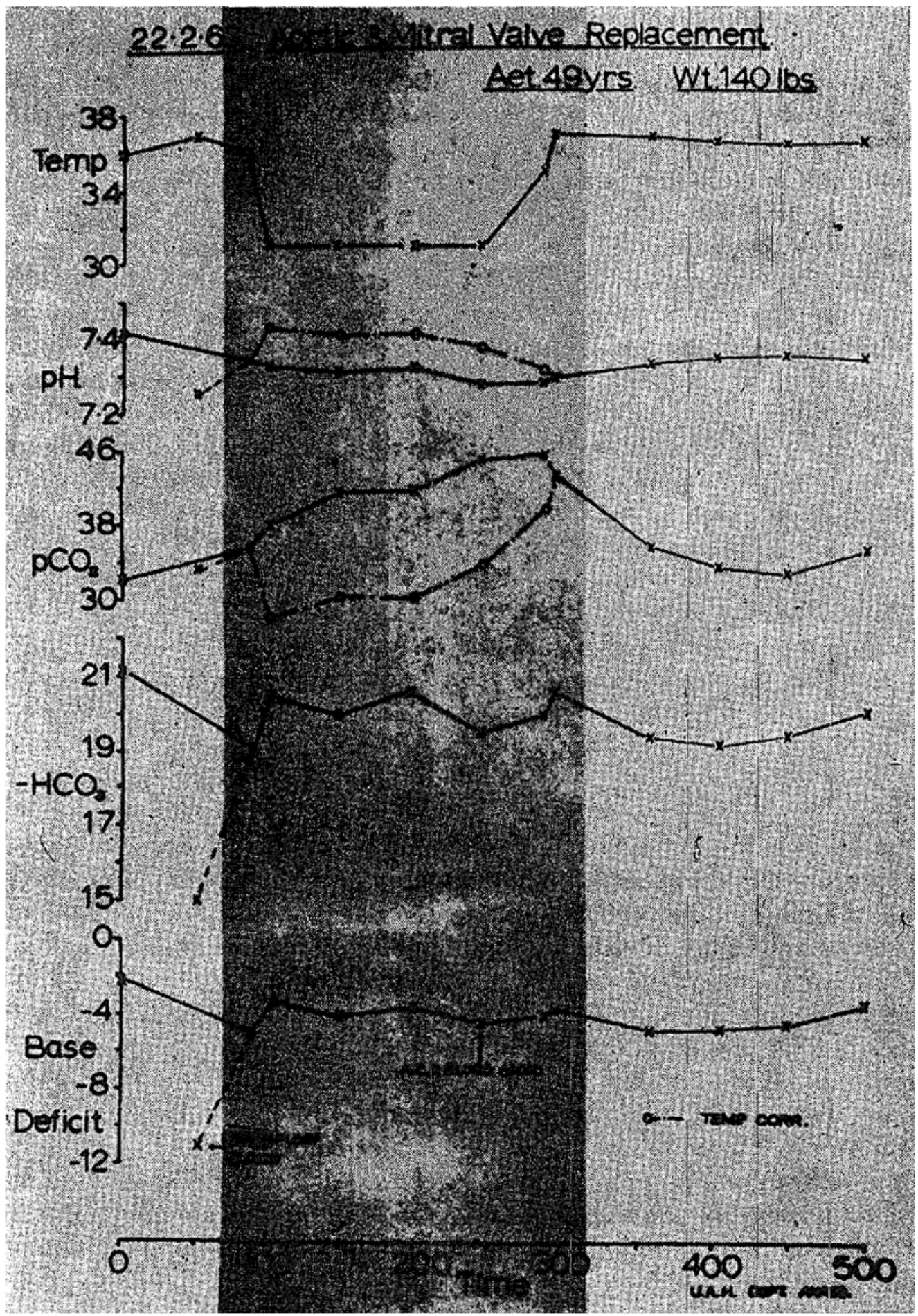

Figune 5. Aortic and mitral valve replacement on a 49 -year-old male of weight 140. lb. Heparin blood used for priming pump. Note stability of parameters during extracorporeal bypass of duration 4 hours 20 minutes: No buffering agents used.

The A.C.D. blood used was "converted" to heparinized blood with the addition of $25 \mathrm{mg}$. heparin $+6 \mathrm{ml}$, of a 10 per cent $\mathrm{CaCl}_{2}$ solution and warmed to $36-37^{\circ} \mathrm{C}$. The $\mathrm{pH}$ was then measured with a standardized technique and usually found to be within the range $6.7-6.8$. Then the 3.6 per cent solution of T.H.A.M. 
was added in an amount equal to approximately lone-fifteenth of the priming volume of blood in the pump "and oxygenator. After mixing, the $\mathrm{pH}$. was'again read and, if necessary, further small amounts of T.H.A.M. were added until the $\mathrm{pH}$ was within the normal range. Once near the normal $\mathrm{pH}$ only small amounts of T.H.A.M. are required to make a large change in $\mathrm{pH}$. On one occasion a $\mathrm{pH}$ of 7.6 was obtained but this caused no haemolysis and the $\mathrm{pH}$ was rapidly restored to normal once the perfusion began,

We rarely get an acidosis when on bypass even' with hypothermia, provided we can maintain adequate flows of 2.2-2.4 litres per square metre of body surface. On the one occasion when a tendency to acidosis did occur whilst on bypass, T.H.A.M. was satisfactory in keeping the $\mathrm{pH}$ within normal limits (Figs. 4 and 5).

So far, we have used T.H.A.M. on 17 cases and it has proved satisfactory in preventing the $\mathrm{pH}$ drop at the commencement of bypass. It seems to us that our patients have benefited from this, but in view of the many, variables present, dogmatic statements cannot be made until a very large series is obtained. It would also seem that A.C.D. blood + T.H.A.M. + calcium is, as Boue implied, as good as fresh heparinized blood and may be safely used where the latter is difficult to obtain. We also believe that thought should be given to pre-buffering blood used in massive replacement therapy for shock anid haemorrhage. Finally we wish to thank Abbott Laboratories for liberal supplies of Talatrol@ (T.H.A.M.) and Mr. John Lewchuk who made some of the analyses and Mr. Brian Lewis A.I.S.T. who made the rest of the analyses and all the figures.

\section{RÉSUMÉ}

Dans le but de diminuer la tension exercée sur la Croix Rouge pour qu'elle nous procure des donneurs de sang frais hépariné, les auteurs ont essayé d'employer du sang citraté reconstitué avec du calcium et de l'héparine pour les malades soumis à la circulation extracorporelle. Le $\mathrm{pH}$ de ce sang reconstitué s'est trouvé parfois dans des limites dạngereuses s'il avait fallu l'employer d'urgence dans le coeur artificiel chez un malade en détresse. En conséquence, nous avons ramené ce sang à un $\mathrm{pH}$ voisin de la normale en augmentant les tampons avec du T.H.A.M.

Nous avons vérifié s'il se faisait de l'hémolyse sur des échantillons de sang auxquels nous avions ajouté la même proportion de T.H.A.M. que celle qui serait utilisée dans la pompe. Nous avons employé une solution isomolaire (3.6\%) et nous avons placé ces échantillons de sang à l'étuve durant 24 heures à des températures de $4^{\circ} \mathrm{C}$, $20^{\circ} \mathrm{C}$. et $37^{\circ} \mathrm{C}$., et nous n'avons pas observé de traces d'hémolyse.

Le sang citraté a été changé en sang hépariné en y ajoutant $25 \mathrm{mg}$. d'héparine, plus $6 \mathrm{ml}$. d'une solution à 10 pour cent de chlorure dè calcium et en le chauffant à $36-$ $37^{\circ} \mathrm{C}$. A ce moment, nous avons mesuré le $\mathrm{pH}$ d’après une technique standardisée et nous l'avons trouvé d'habitude dans les environs de 67-6.8. Nous avons ajouté la solution de T.H.A.M. à 3.6 pour cent en quantité égale approximativement à $1 / 15$ de la quantité de sang nécessaire pour amorcer la pompe. Après agitation du mélange, nous avons fait de nouveaux $\mathrm{pH}$ et, à l'occasion, si nécessaire, nous 
avons ajouté de petites quantités additionnelles de T.H.A.M. jusqu’à ce que le $\mathrm{pH}$ soit dans les limites de la normale.

Jusqu’à présent, les auteurs ont employé du sang additionné de T.H.A.M. chez 17 malades et ce sang s'est avéré satisfaisant pour éviter l'abaissement du $\mathrm{pH}$ pour amorcer la circulation extracorporelle. Nous sommes d'avis que le sang citraté additionné de T.H.A.M. et de calcium est aussi bon que le sang frais hépariné et qu'il peut être employé en toute sécurité là où il est difficile d'obtenir du sang frais. Il serait peut-être bon de songer à employer du sang carbonaté au préalable pour les transfusions massives données comme traitement $\mathrm{du}$ choc hémorragique.

\section{REFERENCES}

1. Foote, A. V.; Trede, M.; \& Maloney, V. Jr. An Experimental and Clinical Study of the Use of Acid-Citrate-Dextrose (ACD) Blood for Extra-Corporeal Circulation. J. Thoracic \& Cardiovasc. Surg. 42: 93-109 (July 1961).

2. Boue, A. E.; Hermann, G.; \& Shaw, R. S. A Study of Bank Blood Toxicity. Surg., Gynec. \& Obst. 113 (No. 1): 40 (1961).

3. Ebert, P. A.; Greenfield, L. J.; Austen, G.; \& Mornow, A. G. The Relationship of Blood $\mathrm{pH}$ during Profound Hypothermia to Subsequent Myocardial Function. Surg., Gynec., \& Obst. 114: 357-362 (March 1962).

4. Schwetzer, O. \& Howland, W. S. Potassium Levels, Acid-Base Balance and Massive Blood Replacement. Anesthesiology 23: No. 6" (Nov.-Dec. 1962).

5. Nafias, G. G.; Jondon, E. C.; " \& Ligou, J. C. The Effects of a $\mathrm{CO}_{3}$ Buffer on the Hypercapnia of Apneic Oxygenation. Am. J. Physiol. 197: 1308 (1959).

6. Rosenthal, T. B. The Effect of Temperature on the $\mathrm{pH}$ of Blood and Plasma in vitro. J. Biol. \& Chem. 173: 25 (1948). 